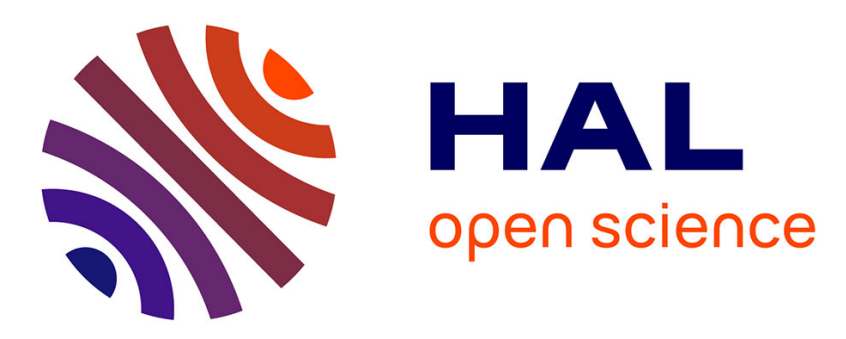

\title{
Elimination of cone and seed pests by wildfire opened a five-year regeneration window in a non-regenerating incense-juniper (Juniperus thurifera L.) stand
}

Alain Roques, Jocelyne Cambecedes, Delphine Fallour-Rubio, Jean-Paul

Raimbault, Philippe Lorme, Marie-Anne Auger-Rozenberg

\section{To cite this version:}

Alain Roques, Jocelyne Cambecedes, Delphine Fallour-Rubio, Jean-Paul Raimbault, Philippe Lorme, et al.. Elimination of cone and seed pests by wildfire opened a five-year regeneration window in a non-regenerating incense-juniper (Juniperus thurifera L.) stand. Ecologia mediterranea, 2013, 39 (1), pp.89-98. hal-02642234

\section{HAL Id: hal-02642234 \\ https://hal.inrae.fr/hal-02642234}

Submitted on 28 May 2020

HAL is a multi-disciplinary open access archive for the deposit and dissemination of scientific research documents, whether they are published or not. The documents may come from teaching and research institutions in France or abroad, or from public or private research centers.
L'archive ouverte pluridisciplinaire HAL, est destinée au dépôt et à la diffusion de documents scientifiques de niveau recherche, publiés ou non, émanant des établissements d'enseignement et de recherche français ou étrangers, des laboratoires publics ou privés. 


\title{
Elimination of cone and seed pests by wildfire opened a five-year regeneration window in a non-regenerating incense- juniper (Juniperus thurifera L.) stand
}

\author{
L'élimination des ravageurs des cônes et graines \\ par un incendie accidentel a ouvert une fenêtre de régénération \\ de cinq ans dans un peuplement de Juniperus thurifera $L$. \\ présentant des difficultés de régénération naturelle
}

Alain ROQUES ${ }^{1 *}$, Jocelyne CAMBECÈDES ${ }^{2}$, Delphine FALLOUR-RUBIO3, Jean-Paul RAIMBAULT ${ }^{1}$, Philippe LORME ${ }^{1}$, Marie-Anne AUGER-ROZENBERG ${ }^{1}$

1. INRA, UR 633, Zoologie forestière, 2163, avenue de la Pomme de Pin, CS 40001 Ardon, 45075 Orléans cedex 2, France

2. Conservatoire botanique national des Pyrénées et de Midi-Pyrénées, Vallon de Salut, BP 315, 65203 Bagnères-de-Bigorre cedex, France

3. Office national des forêts, Bureau d'études «Plaines et Montagnes », Antenne de Saint-Gaudens, 262, route de Landorthe, 31800 Saint-Gaudens, France

*Author for correspondence

\begin{abstract}
The sanitary status of seed cones of incense juniper, Juniperus thurifera, has been surveyed from 2001 to 2011 in a relict population of the French Pyrenees (Rié Mountain, Haute-Garonne, France) which has been severely affected by a wildfire during the summer 2003. Damage to seed and cones was compared on the same trees before and following the 2003 fire. Before the fire, natural regeneration was severely hindered by the joint damage of a seed mite, Trisetacus quadrisetus, and a seed chalcid, Megastigmus thuriferana which limited to 25-55 the number of sounds seeds falling on the ground per tree. The fire destroyed a large part of the stand but simultaneously killed most of insect seed predators. No flowering was observed the following year (2004), thus contributing to eliminate the remaining predators. In spite of large annual fluctuations, more than 200 sound seeds were dispersed on the average per tree in 2006 and
\end{abstract}

Keywords: pests, Juniperus thurifera, seed cones, seeds, natural regeneration, fire.
2009, i.e. 4-10 times more than before the fire. Seed chalcids and mites only began to recolonize the stand during summer 2008, probably originating from nearby stands of J. thurifera (chalcids) or J. communis (mites). Although the pest populations regularly increased every year, cone damage remains concentrated on less than ten trees. Unexpected events such as wildfires may thus play a regulating role upon seed predation by arthropods and opened a regeneration window of five years at least, as it can be observed from the sudden appearance of numerous seedlings during this period.

\section{Résumé}

L'évolution du potentiel de régénération naturelle de la population pyrénéenne relique de Juniperus thurifera de la montagne de Rié (Haute-Garonne, France) a été surveillée de 2001 à 2011, avant et après l'incendie qui a

Mots clés : ravageurs, Juniperus thurifera, galbules, graines, régénération naturelle, incendie. 
détruit une large partie de ce peuplement en 2003. La production de galbules, leur état sanitaire de la floraison à la maturité, et le nombre de graines viables résultantes ont été mesurés chaque année sur les dix mêmes branches de dix arbres différents. Avant l'incendie, l'impact conjugué du chalcidien des graines, Megastigmus thuriferana, et des acariens des galbules, Trisetacus quadrisetus, réduisait de manière drastique le potentiel de régénération naturelle du Genévrier thurifère, avec seulement 25 à 55 graines pleines tombant au sol en moyenne par arbre. L'incendie de 2003, survenu pendant une période où les ravageurs ne pouvaient s'échapper des galbules, a conduit à l'élimination complète de leurs populations sur le site. Après une année de reprise sans floraison, l'absence des ravageurs s'est traduite par une augmentation significative du potentiel de régénération du thurifère par rapport à la situation prévalant avant l'incendie. Malgré des variations interannuelles de fructification, plus de 200 graines pleines sont tombées en moyenne au sol par arbre fructifère en 2006 et en 2009, soit de quatre à dix fois plus qu'en 2002-2003. La recolonisation du site par les chalcidiens et acariens n'a commencé qu'à l'été 2008, probablement à partir de populations voisines de J. thurifera (chalcidiens) ou J. communis (acariens). Malgré une augmentation progressive des populations de ravageurs, les dégâts restent concentrés jus$q u$ 'à maintenant sur moins de dix arbres. L'incendie paraît avoir ainsi joué un rôle régulateur sur la prédation des graines par les ravageurs, avec l'apparition d'une fenêtre de régénération de l'ordre de cinq années comme l'attestent les nombreuses jeunes plantules apparues sur le site après l'incendie.

\section{Introduction}

Many factors are susceptible to affect the natural regeneration of conifer trees (Rodrigo $e t$ al. 2004; Verheyen et al. 2009). Among them, arthropod damage to cones and seeds during the pre-dispersal phase may be considered to play a key role because it may severely decrease the annual number of seeds then available for germination (Turgeon et al. 1994). Extensive surveys of the impact of cone and seed pests were carried out since a long time in economically important species of the family Pinaceae (e.g., Abies, Larix, Picea, Pinus, and Pseudotsuga spp.; for a review, see Turgeon et al. 1994). In contrast, little remains known about the damage due to the fauna exploiting the seed cones of Cupressaceae, with the exception of evergreen cypress, Cupressus sempervirens L. (Guido et al. 1998; Battisti et al. 1999, 2003; Roques et al. 1999), and common juniper, Juniperus communis L. (Garciá, 1998, 2001; Garciá et al. 2000, 2002; Falke, 2004; Rouault et al. 2005; Verheyen et al. 2009). Conservation purposes recently led to investigate whether the arthropods damaging seeds could constitute, besides the effects of human activity, an aggravating factor hindering the preservation of some endangered Cupressaceae species such as the Atlas cypress, Cupressus atlantica Gaussen, and the incense juniper, Juniperus thurifera L. (El Alaoui El Fels \& Roques 2006a).

For example, insects and mites developing in cones of $J$. thurifera have to been shown to limit drastically the number of viable seeds susceptible to be dispersed in the Atlas Mountains of Morocco (El Alaoui El Fels et al. 1999a; El Alaoui El Fels \& Roques 2006b). In these areas, pest damage was observed to decrease the average number of sound seeds to less than 0.2 per cone, resulting in a very low probability of regeneration because of the subsequent action of other mortality factors following germination (El Alaoui El Fels et al. 1999a). A similar high impact of cone and seed pests was also noticed in other parts of the patchy range of this juniper species such as the French Alps and Corsica (Roques et al. 1984) and the French Pyrenees (Roques \& Auger-Rozenberg 2006). In both Morocco and France, the natural regeneration of native stands usually appeared very limited, and even quite non-existent in most cases. In contrast, the recruitment of young seedlings was commonly observed in Spain although overall pest damage did not seem to differ significantly from the value observed in Morocco (El Alaoui El Fels et al. 1999b). Indeed, Roques \& El Alaoui El Fels (2002) showed that the number of viable seeds remaining in cones following pest damage is positively correlated with the initial number of seeds; thus, an initial number of seeds per cone higher in the Spanish stands than in the Moroccan and French ones may partly explain the observed differences in natural regeneration. For the same reasons, J. oxycedrus L. and J. phoenicea L. may be favored by their higher number of seeds when they grow in sympatry with $J$. thurifera (Roques \& El Alaoui El Fels 2002).

In many conifers, 'masting' (i.e., the synchronous production of large seed crops at variable intervals; Silvertown 1980), is a common reproductive phenomenon. Seed production is highly irregular in both space and time, 
which results in large annual variations in seed predation with an inverse relationship between the damage percentage and the change in cone crop size from the past year to the current year (Turgeon et al. 1994; Poncet et al. 2009; Auger-Rozenberg \& Roques 2012). In some years, a sudden, sharp increase in cone abundance is likely to outpace the increase in arthropod populations and their ability to attack cones, and as a result a large quantity of seeds would escape from predation and contribute to the regeneration process (Predator Satiation hypothesis; Janzen 1971; Silvertown 1980). However, an 8-year study in the Middle Atlas Mountain revealed a quite different figure in $J$. thurifera. The fluctuations in the annual cone abundance appeared limited whereas cone damage varied quite in parallel but never dropped below 30\% (Roques \& El Alaoui El Fels 2002). It has been hypothesized that unpredictable events such as late frosts, which may suddenly kill the available flowers, or wildfires, are susceptible to break such equilibrium between juniper cones and the populations of associated arthropods, and thus favor natural regeneration (Roques \& Auger-Rozenberg 2006).

An occasion to study this process has been given by the occurrence in summer 2003 of a wildfire which destroyed the major part of a rather isolated stand of $J$. thurifera in the French Pyrenees, which had been previously monitored for arthropod damage (Cambecèdes et al. 2005). Before the fire, only three phytophagous species attacked cones and seeds in this stand, which corresponded to a low species richness compared to Morocco (8 species), the Alps and Spain (4 species) (Roques \& Auger-Rozenberg 2006). Only two of these species were effectively affecting seed yield. A seed chalcid, Megastigmus thuriferana Roques et El Alaoui (Hymenoptera: Torymidae), is specialized in the exploitation of seeds of $J$. thurifera (Auger-Rozenberg et al. 2006). Using its ovipositor, the female chalcid lays eggs directly into the seeds where the whole larval development will take place, with only one larva per seed. The mite, Trisetacus quadrisetus Thomas (Acarina: Eriyophiidae), is galling the seeds which then protrude noticeably through cone surface (El Alaoui El Fels \& Roques 2006a). However, this species is oligophagous, being also observed on other junipers such as J. communis L. J. sabina L., $J$. oxycedrus, and J. phoenicea (Roques
1983). The third species, a scale, Carulaspis juniperi (Bouché) (Hemiptera: Diaspididae), is observed on all juniper species in Europe (Graora et al. 2010). It develops and feeds on the outer part of the cone of J. thurifera but it seems to have no impact on seed viability (Roques \& Auger-Rozenberg 2006). Because the three species were either too tiny to move or larvae concealed in seeds when the fire occurred, the major part of their populations could not escape the burning or the too hot temperatures observed in the areas that were not completely burnt. The few survivors disappeared during the following year because no cones were available at all in the stand (Roques \& Auger-Rozenberg 2006). It has thus been hypothesized that a regeneration window may exist if the stand succeeds in flowering again before the cone and seed pests recolonize it. Wildfires are known to be responsible for massive seed release in conifer species with serotinous cones (Baskin \& Baskin 1998). However, the relationships with cone and seed consumers were little investigated except in a few angiosperms with seed capsules. In the Australian Eucalyptus baxteri (Benth.) Maiden \& Blakely ex J.M. Black and Casuarina pusilla Macklin, massive seed release following fire can lead to predator satiation and large subsequent recruitment of seedlings (Andersen 1987).

Therefore the objectives of our study were to 1) to test whether the disappearance of cone and seed pests following the 2003 wildfire resulted in a significant increase in the number of sound seeds available for germination; 2) to monitor the possible recolonization of the stand by the pests and to assess the time during which the stand would remain free of any pest; and 3), to measure the dynamics of seed damage after recolonization.

\section{Material and methods}

\section{Monitoring of cone and seed damage before and following the 2003 wildfire}

The monitoring procedure followed the one described by Roques \& Auger-Rozenberg (2006) in order to survey the complete development of a cone generation, from initiation to seed maturity. In 2002, 15 trees with female cones were randomly selected in the stand, 
and two branches per tree were tagged in early June. The total number of $1^{\text {st }}$ - and $2^{\text {nd }}$ year cones present on the tree was visually estimated. The position of all of the $1^{\text {st }}$-year cones present of the tagged branches was mapped, and their sanitary status checked. All the $2^{\text {nd }}$-year cones (i.e., from generation 2001) present on the tagged branches were then collected and dissected to identify possible damage to species. Their seeds were extracted and individually radiographed in order to measure the respective numbers of filled, empty and infested seeds. Seed radiography was carried out using a Faxitron $43855 \AA$ apparatus $(15 \mathrm{Kv}$, 3mA, 3'30") and X-ray sensitive films (Kodak® "Industrex M"). The infested seeds were placed in individual rearing boxes stored in an outdoor insectary located at INRA,

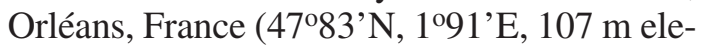
vation), according to the method defined by Roques \& Skrzypczyńska (2003). Adult emergence was surveyed over the two years following seed collection because of a possible prolonged diapause.

The same trees and branches were visited again in late October to check the survival of the $1^{\text {st }}$-year cones and to assess possible damage. The following year, the surviving cones having turned to $2^{\text {nd }}-$ year cones on the tagged branches were counted, collected and treated as above whereas the newly- appeared $1^{\text {st }}$-year cones were counted and mapped.

However, the 2003 fire resulted in the complete burning of six of the tagged trees whilst the branches of four more trees did not resprout the years after. Thus, only five of the original trees were available for further monitoring. Because no flowering occurred in 2004, we could only add in June 2005 ten more flowering trees, which were selected at random. These 15 trees (five original and ten added in 2005) were monitored similarly as above two times a year from 2005 to 2011 .

In order to get a more precise spatial estimation of the recolonization of the stand by cone pests, 12 additional trees were sampled in 2011, with a collection of $301^{\text {st }}$-year and 30 $2^{\text {nd }}-$ year cones per tree. All the cones were dissected, and their seeds X-rayed, in order to assess the presence and numbers of cone pests.

\section{Data analysis}

The following variables were measured every year on each tagged branch and their mean values were compared between the periods preceding and following the 2003 fire: 1) number of $1^{\text {st }}$-year cones initiated in spring; 2) percentage of $2^{\text {nd }}$-year cones remaining on branch at maturity in autumn with regard to the initial number of $1^{\text {st }}$-year cones; 3 ) percentage of cones damaged by herbivores; 4) specific percentage of cone damage per herbivore species; 5) mean number of seeds per cone; 6) proportion of sound, infested and empty seeds; 7) mean number of filled seeds. Seed damage was calculated as the ratio of infested seeds on the number of seeds considered as available for pest development, i.e. filled seeds plus infested seeds (Roques \& Skrzypczyńska 2003). Then, the total number of filled seeds potentially- dispersed per tree was extrapolated from the percentage of sound seeds per branch and the total number of $2^{\text {nd }}$-year cones remaining on tree at maturity. In order to harmonize the assessments, the data will be presented by cone generation; i.e. generation 2001 will correspond to $1^{\text {st }}$-year cones analyzed in 2001 but to $2^{\text {nd }}$ year cones and seed yield analyzed in 2002 . Because neither the overall seed damage nor the specific damage followed a normal distribution (Kolmogorov-Smirnov test), the comparisons were done using a non-parametric Kruskal-Wallis test.

\section{Results}

\section{Annual variation in flowering magnitude and in size of the final crop before and following the 2003 fire}

The mean number of $1^{\text {st }}$-year cones per branch largely varied between years, with intervals of 2-3 years between years of large flowering (Figure 1). Less than forty $1^{\text {st-year }}$ cones were observed per branch before the 2003 fire. No flowering at all occurred the year following the fire (2004) but $1^{\text {st }}$-year cones appeared again in 2005 at a magnitude larger than previously. Then, periods of low flowering alternated with years of large flowering to culminate with ca. seventy $1^{\text {st }}$-year cones per branch in 2011. 


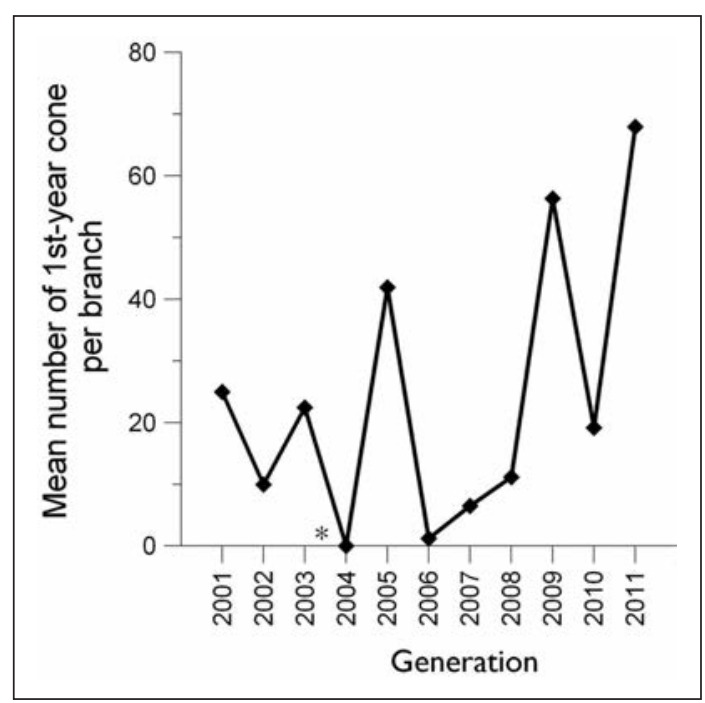

Figure 1 - Annual variation in the mean number of $1^{\text {st }}$-year cones having appeared from spring 2001 to spring 2011

on the branches surveyed at Rié.

*: Fire occurrence.

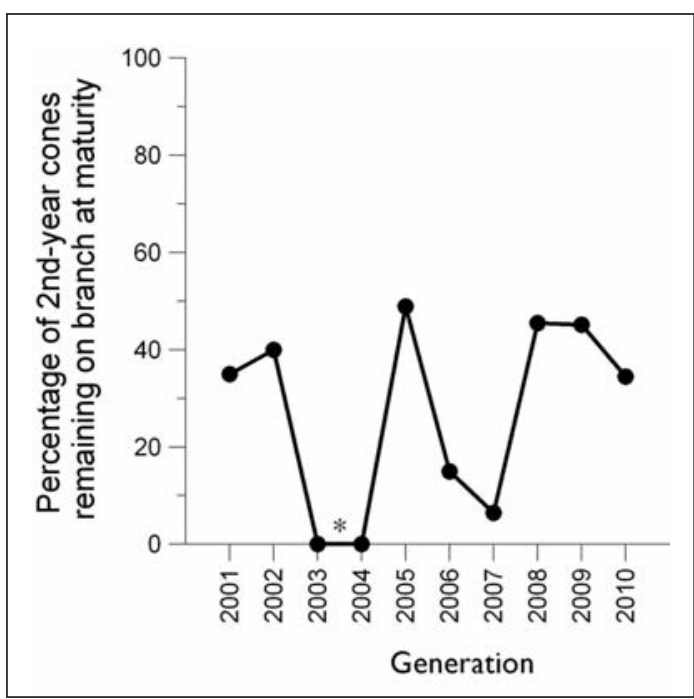

Figure 2 - Annual variation in the proportion of $2^{\text {nd }}$-year cones remaining at maturity on the branches surveyed at Rié from 2001 to 2011. Data are presented by cone generation, meaning that generation $N$ corresponds to mature cones still present on branches in autumn $N+1$.

*: Fire occurrence.

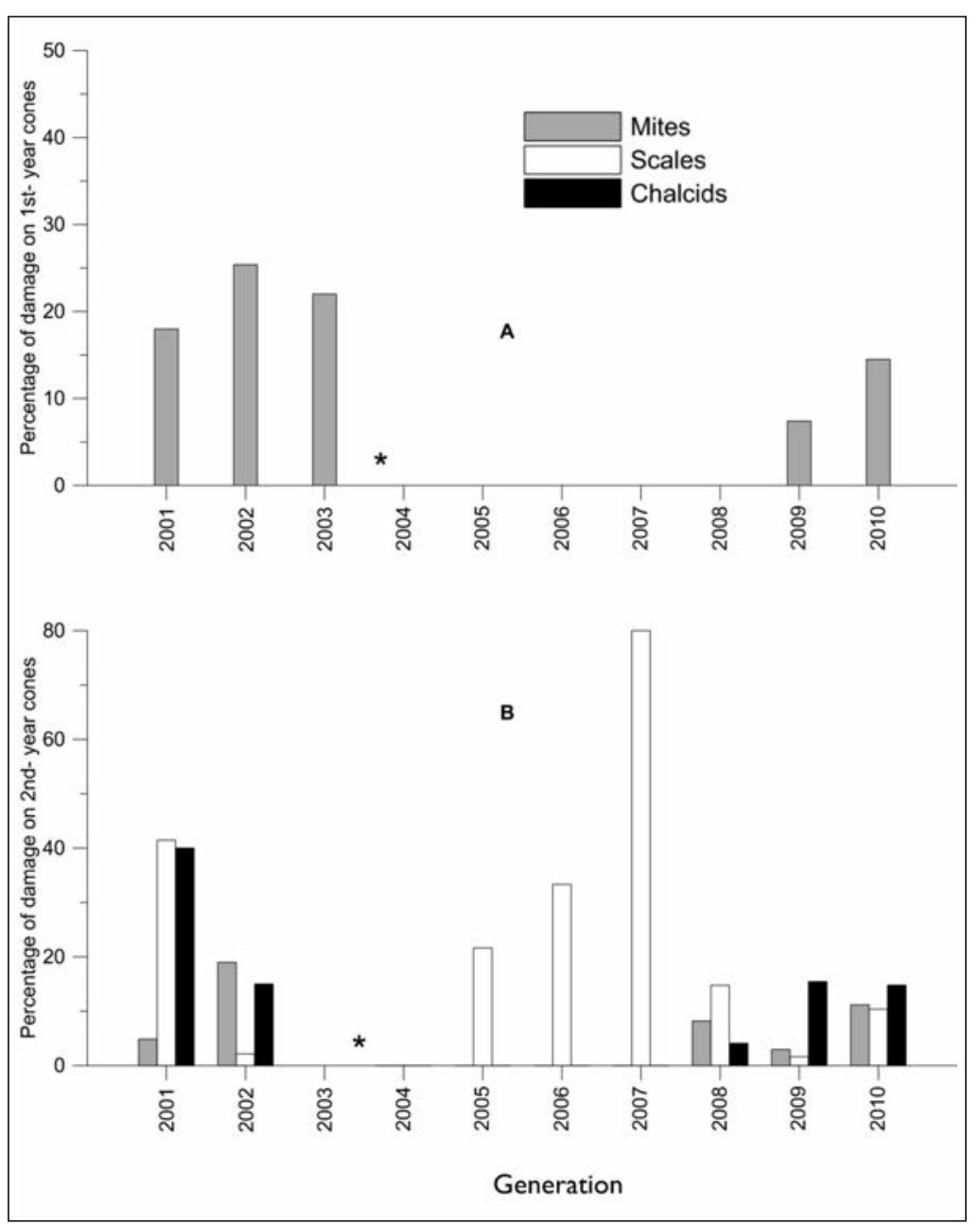

Figure 3 - Cone damage caused by the different species of arthropods on the branches surveyed at Rié from 2001 to 2011. A-Damage to $1^{\text {st }}$-year cones; B-Damage to $2^{\text {nd }}$-year cones. Data are presented as in Figure 2. *: Fire occurrence. 
However, overall damage remained still lower than in the generations 2001-2003, and did not exceed $14.5 \%$ in $1^{\text {st }}$-year cones (Figure $3 \mathrm{~A}$ ) and $26.0 \%$ in $2^{\text {nd }}$-year cones when mite and chalcid damage are added (Figure 3B).

Before the fire, all of the surveyed trees were attacked by either chalcids or mites. After the fire, the number of infested trees remained low (eight in total) after the pests have reappeared since 2009. Three of the 15 surveyed trees were attacked in 2009 (generation 2008), only one in 2010 (generation 2009), but the infestation extended to six trees in 2011 (two from the original survey and four from the additional collection of 12 trees). Only one tree was attacked every year during these three years (Figure 4). Mites recolonized a total of seven trees up to now whereas chalcids were observed on two trees, only one tree sharing both pests.

\section{Annual variation in dispersal of sound seeds before and following the 2003 fire}

The total number of seeds per mature cone averaged $2.58 \pm 0.06$ for the generations 2001 and 2002 preceding the fire. The values observed in the years following the fire were not significantly different (average 20052010: $2.51 \pm 0.05$; Kruskal-Wallis test; $\mathrm{P}=0.076$ ).

Before the fire, the percentage of filled seeds did not exceed $20 \%$ of the total seeds whereas it was always higher for the generations 2005 to 2008 (i.e., mature seeds of years 2006 to 2009), reaching up to $45 \%$ for the generation 2008 (Figure 5A). This percentage largely decreased during the two following years. In contrast, empty seeds represented more than $40 \%$ of the total seeds whatever the year, and more especially in 2011 (generation 2010) where they accounted for up to $87 \%$ of the total seeds.

Mites and chalcids were destroying up to $40 \%$ of the total seeds in 2002 (generation 2001) but then, any damage disappeared until 2009 (generation 2008). In the following years, the proportion of infested seeds increased again but never exceeded $15 \%$ of the total seeds. When only sound and infested seeds were considered, seed damage decreased by 42.4 to $64.8 \%$ the expected seed yield before the fire (Figure 5B). After a 5-year period where this damage was nil, it only decreased by $24.1 \%$ the expected seed yield of the generation 2008 but in the following years the values became similar to these observed before the fire.

The presence of scales on the outer part of cones did not affect negatively seed health. A specific analysis carried out on a lot of 150 $2^{\text {nd }}$-year cones of the generation 2005 even revealed that cones colonized by scales contained significantly more seeds $(3.2 \pm 0.2$ vs. $2.5 \pm 0.2$ in cones without scales; KruskalWallis test; $\mathrm{P}=0.0199$ ), and included a higher percentage of sound seeds $(59.9 \pm 7.9 \%$ vs. $13.8 \pm 3.2 \%$; Kruskal-Wallis test; $\mathrm{P}=0.0000$ ). A similar analysis was carried out in 2010 on cones infested by seed chalcids in the single tree they infested during that year. Only one seed was attacked in $38(81 \%)$ of the 47 infested cones whereas eight cones showed two infested seeds (17\%), and only one cone had three seeds attacked (2\%). The cones attacked by chalcids also contained significantly more seeds $(3.72 \pm 0.18)$ than the healthy ones $(2.03 \pm 0.15)$ (Kruskal-Wallis test; $\mathrm{P}=0.0000$ ).

The total number of filled seeds was extrapolated to an average of less than 55 per tree before the fire (Figure 6). After the fire, this average number increased to more than 200 in 2006 (generation 2005) and 2009 (genera-

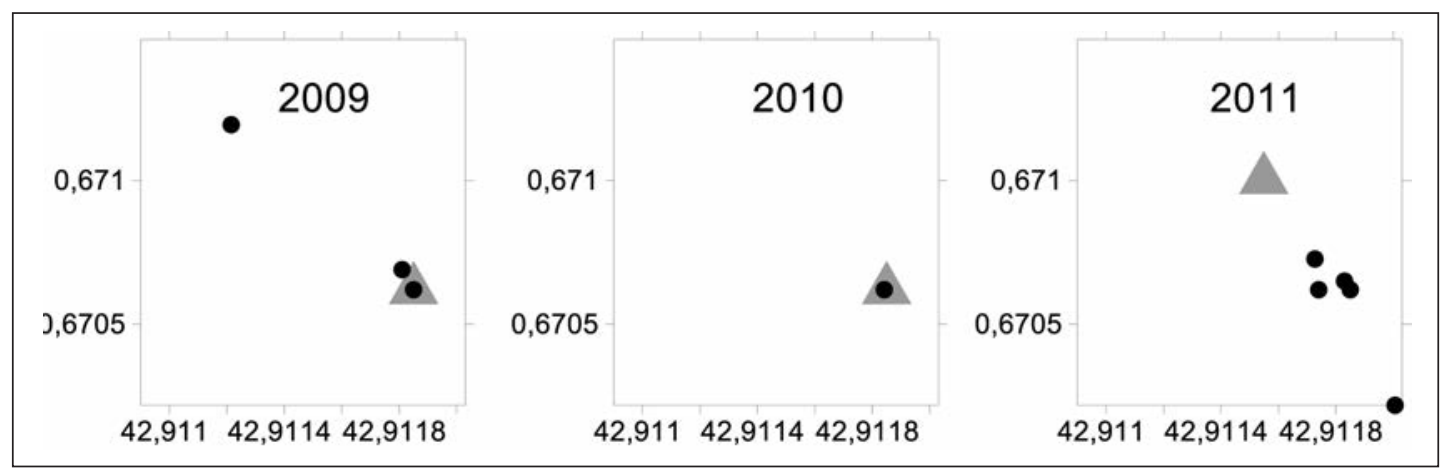

Figure 4 - Spatial position of the trees recolonized after the fire by the chalcid Megastigmus thurifera (triangle) and the mite Trisetacus quadrisetus (circle). 
tion 2008) when the pests were not present or just began to recolonize. Then, it decreased again during the following years. However, large variations were observed between trees, the number of filled seeds susceptible to be dispersed per tree varying from 0 to 350 . Considering all the surveyed trees, up to 3600 filled seeds were available for dispersal in 2006 (generation 2005) and still more than 2000 in 2009 (generation 2008) (Figure 6).

\section{Discussion}

Our survey showed that the 2003 wildfire resulted in a complete disappearance for a 5 -year period of the pests affecting seed cones during the pre-dispersal phase. A few individuals might have survived to fire and high temperatures in areas which were little burnt but the null crop observed in 2004 led the populations to disappear since no prolonged diapause allowing an escape in time is apparently existing in these species (Roques, unpublished. results). Because the Megastigmus larvae observed in seeds in June 2009 were necessarily issued from eggs deposited during July 2008, the recolonization by chalcids probably began at that time. It is likely that the recolonizing chalcids originated from nearby populations developing on $J$. thurifera at Bezins-Garraux and St Béat, two small stands distant of ca. $5 \mathrm{~km}$, where $4-5 \%$ of the cones were observed to be attacked by chalcids in 2006-2007 (Roques, unpublished results). Mites were first observed during spring 2009 on both $1^{\text {st }}$-year and $2^{\text {nd }}$-year cones but it is not known whether they can directly attack $2^{\text {nd }}$-year cones (i.e. in 2009) or if they must first develop in $1^{\text {st }}$-year cones (i.e., attack in 2008). These oligophagous mites may have switched from cones of Juniperus communis, several shrubs of this species present in the same valley having not been affected by the fire. Another oligophagous species common on junipers, the scale Carulaspis juniperi, profited from the absence of the major pests to occupy the emptied niche. Scales re-appeared as soon as cones were available in 2005 and their populations colonized up to $80 \%$ of the cones in 2008. Mendel et al. (1997) also noticed that a scale insect, Matsucoccus josephi Bodenheimer \& Harpaz, rapidly recolonized the young seedlings which have appeared following a wildfire in a stand of Aleppo pine,

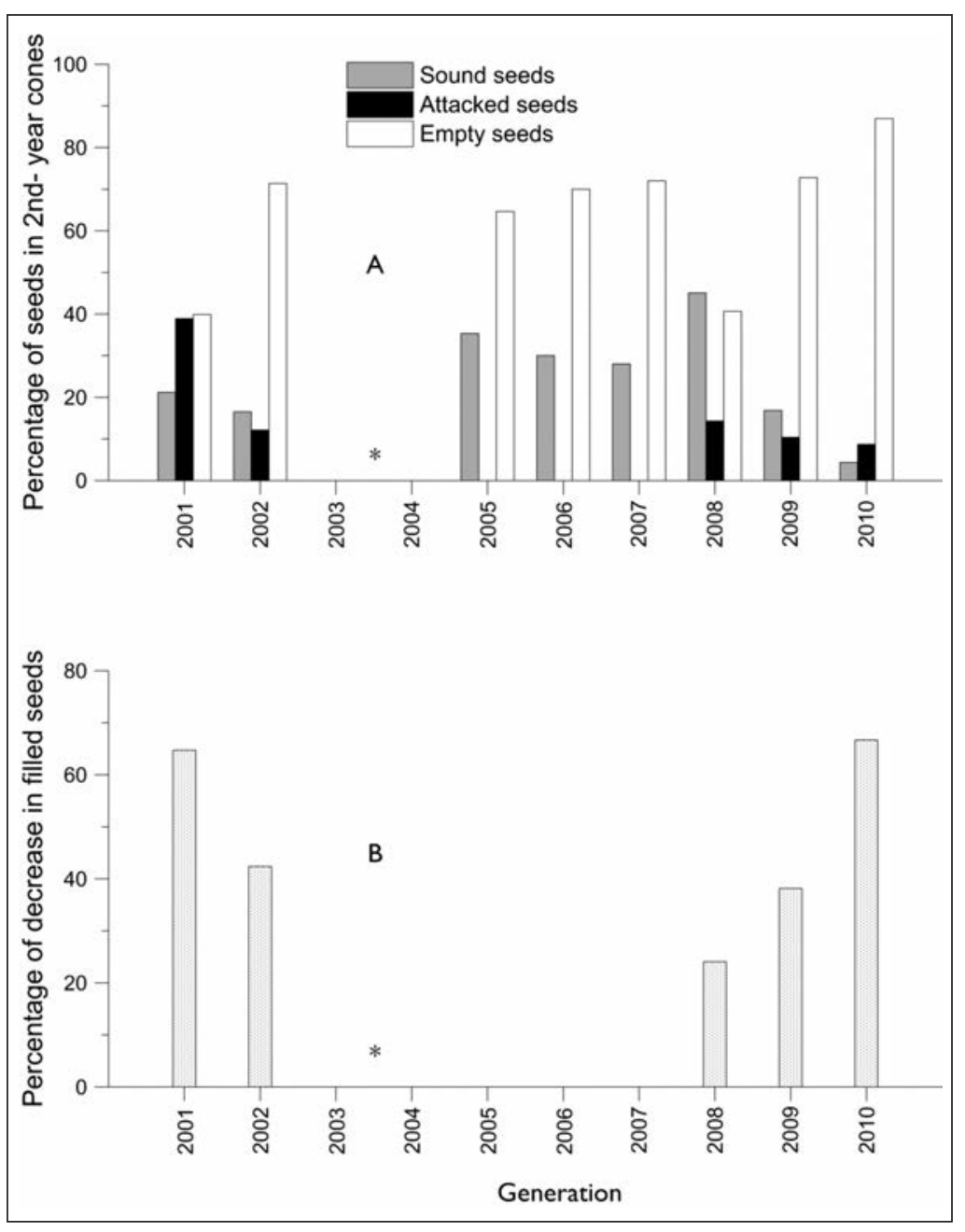

Figure 5 - Annual variation in the sanitary status of the seeds present in the $2^{\text {nd }}$-year cones remaining at maturity on the branches surveyed at Rié from 2001 to 2011. A-Proportion of sound, infested and empty seeds vs. total seeds; $B$ - decrease in seed yield due to pests. Data are presented as in Figure 2. *: Fire occurrence.

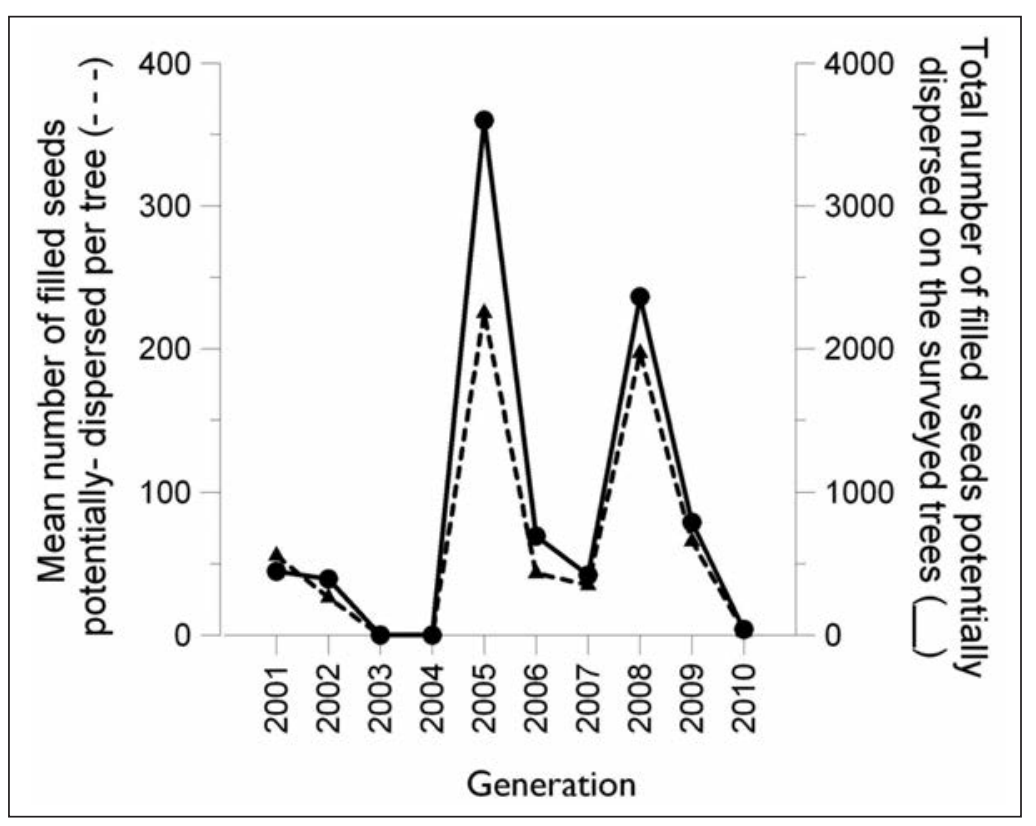

Figure 6 - Extrapolation of the annual numbers of filled seeds potentially dispersed by the surveyed trees from 2001 to 2011. Data are presented as in Figure 2. 
Pinus halepensis Mill. Thus, cone scales were apparently much more mobile at the adult stage than the other species. However, their importance rapidly decreased when chalcids and mites reappeared. Moreover, we confirmed that the scales have no impact on seeds but prefer to attack cones with a higher seed content and a higher number of filled seeds. A similar selection process seemed to occur for Megastigmus. The cones attacked by chalcids also contained significantly more seeds than the uninfested ones present on the same tree. This did not seem true for mites but large differences in mite damage were noticed between trees, similarly as Guido et al. (1995) observed for a congeneric mite, Trisetacus juniperinus Nalepa, attacking cones of evergreen cypress, Cupressus sempervirens.

The disappearance of chalcid and mite pests immediately resulted in a significant increase in the number of sound, filled seeds susceptible to be dispersed, the more as a very large flowering occurred two years after the fire (a delayed consequence of the fire?). Then, the recolonization process by cone pests was rather slow, and only affected a limited number of trees which were rather spatially concentrated until 2011 when mites expanded significantly but not chalcids. As a consequence of this slow recolonization, in spite of annual fluctuations in the flowering magnitude the canopy seed bank extrapolated per tree was every year from 2006 to 2010 larger than the values observed before the fire, and especially 4 to 10 times larger in 2006 and 2008, respectively. However, the high proportion of empty seeds limited the potential size of the canopy seed bank in most years. This was especially true in 2011 where quite no seeds were dispersed whilst the pest damage was still low. The causes could not be identified yet but they were apparently not related to fire occurrence. The large variation in the proportion of empty seeds among trees (e.g., ranging from 47 to $100 \%$ of the total seeds in 2010) led to hypothesize pollination problems, genetic incompatibility, or inbreeding.

As a probable consequence, new seedlings began to be observed at a high frequency since 2006 on. A survey in 2010 noticed 261 seedlings with a stem diameter smaller than $2 \mathrm{~cm}$ (Cambecèdes et al. 2010). Although a few may have pre-existed to the fire, it is likely that most of these seedlings were issued from seeds having germinated after the fire. In 2010, this category of seedlings predominated, represent- ing $30.8 \%$ of all $J$. thurifera trees in the pure stand whereas they accounted for less than $10 \%$ in 2001 (Cambecèdes et al. 2010). Although the canopy seed bank was much larger during the years following the fire, it could not be excluded that some new seedlings were issued from the ground seed bank constituted before the fire. However, to sustain this hypothesis there was no data about the germinating capability of J. thurifera seeds following a wildfire. In the congeneric $J$. phoenicea, tests using buried seeds showed a rapid decrease in seed viability after a fire, $46 \%$ of the buried seeds remaining viable after 1 year but less than 5\% after 2 years (Clemente et al. 2004).

The effects of fire will also depend on when the burn occurs within a plant's reproductive life cycle compared to the dynamics of pest populations. Thus, Peters et al. (2005) suggested that masting is a key process that interacts with fire to shape stand composition in boreal mixedwoods of white spruce, Picea glauca (Moensch) A. Voss. Small mammals, insects, and birds consumed most seeds in years with low to moderate cone crops, and spruce density was significantly lower after fires that occurred 1-3 years before a mast year than after fires occurring during mast years.

Besides wildfires, it can be noticed that prescribed burning was used as a management method to control populations of cone beetles (Conophthorus spp.; Coleoptera: Scolytidae) affecting seed production in white (Pinus strobus [L.]) and red (P. resinosa Ait.) pines in North America (Miller 1978; Wade et al. 1989). Miller (1978) showed that burning of naturally accumulated fuels in red pine stands significantly increased by $11-45 \%$ the number of cones free of all cone-destroyers. However, prescribed litter burning in J. thurifera may have little effect on the population density of cone and seed pests because their life cycle usually takes place in the cones remaining on tree, and rarely in these fallen on the ground. Evaluating the effects of seed predators on post-dispersal seed removal and early seedling establishment of Pinus nigra, Ordóñez \& Retana (2004) also showed that recently burnt areas were the most favorable habitat for recruitment. These areas have both the lowest vegetation cover and the lowest abundance of granivorous ants because there was mortality after fire and new colonizers had not yet established. Another mechanism has been shown in the Australian Eucalyptus baxteri and Casuarina pusilla where fire 
induces a massive seed release, then resulting in predator satiation and large subsequent recruitment of seedlings (Andersen, 1987). In contrast, although fire usually destroys most of the original insect communities in the ecosystem, some pre-adapted species have developed strategies to take advantage of the newly created, competition- free environment, comprised of pre-killed trees. Cerambycids (e.g. from genera Acmaeops, Arhopalus, and Monochamus), and Buprestids (e.g. from genera Melanophila and Buprestis) are wellknown examples of such pyrophilous species, some attracted to smoke and some by heat (Boulanger \& Sirois 2007; Saint-Germain et al. 2008).

In conclusion, wildfires could constitute a key factor in the natural regeneration process by breaking the relative equilibrium existing between populations of cones and these of cone and seed pests, where most seeds are usually predated year after year. This disappearance of the cone pests would open a 'regeneration window'; in this case of 5 years at least taking into account the slow recolonization process by pests. Such sporadic regeneration events in particular years could explain why many stands are even-aged. Indeed, Gauquelin et al. (2003) observed that most trees in this stand were aged of less than 150 years before the 2003 fire, which is rather young with regard to the longevity on $J$. thurifera trees, and they suggested that successive wildfires might have occurred in the past centuries to shape the stand.

However, the overall regeneration process is much more complex, involving many other environmental factors affecting germination and seedling establishment and growth. For example, most trees of Juniperus procera C.F. Hochstetter ex. Endlicher failed to regenerate following forest fire in Saudi Arabia (Aref $e t$ al. 2011). Even forest species, that usually regenerate well after fire, such as Pinus halepensis or Pinus pinaster, show irregular or low regeneration when post-fire environmental conditions are not favorable for seed germination (Rodrigo et al. 2004).

\section{Acknowledgements}

We greatly acknowledge financiary support from DiREN Midi-Pyrénées, conseil régional de Midi-Pyrénées and National Forestry
Office for the site Natura 2000 FR77300884 «Zones rupestres xérothermiques du bassin de Marignac, Saint-Béat, pic du Gar, Montagne de Rié », called «Gar-Cagire ». This study was partly funded by a grant from the French «Agence nationale de la recherche » (International project MacBi- Megastigmus and conifers: the biology of invasion- ANR2010-INTB-1705).

\section{References}

Andersen A. N., 1987. Effects of seed predation by ants on seedling densities at a woodland site in SE Australia. Oikos 48: 171-174.

Aref I. M., El-Atta H.A. \& Al-Ghamde A.R.M., 2011. Effect of forest fires on tree diversity and some soil properties. International J. Agric. Biol. 13: 659-664.

Auger-Rozenberg M.A., Kerdelhué C., Magnoux E., Turgeon J., Rasplus J.Y. \& Roques A., 2006. Molecular phylogeny of conifer seed chalcids in the genus Megastigmus (Hymenoptera: Torymidae) and evolution of host-plant use. Syst. Entomol. 31: 47-64.

Auger-Rozenberg M.A. \& Roques A., 2012. Seed wasp invasions promoted by unregulated seed trade affect vegetal and animal biodiversity. Int. Zool. 7 : 228-246.

Baskin C.C. \& Baskin J.M., 1998. Seeds: Ecology, Biogeography, and Evolution of Dormancy and Germination. New-York, Academic Press, 666 p.

Battisti A., Cantini R., Rouault G. \& Roques A., 2003. Serotinous cones of Cupressus sempervirens provide viable seeds in spite of high seed predation. Ann. For. Sci. 60: 781-787.

Battisti A., Roques A., Colombari F., Frigimelica G. \& Guido M., 1999. Multiple insect-fungus association in the cypress seed cone. Naturwiss. 86: 479-483.

Boulanger Y. \& Sirois L., 2007. Postfire succession of saproxylic arhtropods, with emphasis on Coleoptera, in the north boreal forest of Quebec. Environmental Entomology 36: 128-141.

Cambecèdes J., Candy F., Faucheux B., Rachou-Langlatte F. \& Fallour-Rubio D., 2010. Suivi de la dynamique de la population de Genévrier thurifère sur la montagne de Rié (Marignac, 31). Syndicat mixte, Conservatoire botanique pyrénéen, Vallon de Salut, BP 315, 65203 Bagnères-de-Bigorre, 28 p.

Cambecèdes J., Gauquelin T., Roques A., Thébaut C., Burrus M., Gardes M., Gryta H., Joachim J., Bertaudière V., Renaux T. \& Largier G., 2005. Approche intégrée de la conservation des populations pyrénéennes de Genévrier thurifère (Juniperus thurifera L.). Toulouse, Bull. Soc. Hist. Nat. 141-2 : 189-195.

Clemente A. S., Rego F. C. \& Correia O., 2004. Padroes de sobrevivencia de sementes em grupos funcionais de resposta ao fogo. Revista de Biologia (Lisboa) $22: 123-132$.

El Alaoui El Fels M.A., Roques A. \& Boumezzough A., 1999a. Les arthropodes liés aux galbules et aux graines du Genévrier thurifère, Juniperus thurifera L., dans les Atlas marocains. Ecol. Medit. 25 : 95110.

El Alaoui El Fels M. A., Blasco-Zumetta J., Bigot L., Boumezzough A. \& Roques A., 1999b. Contribution 
à la diversité faunistique dans deux peuplements à Genévrier thurifère au Maroc (Tizrag) et en Espagne (Monegros). In: Journées « État de l'environnement et biodiversité des systèmes terrestres », 20-23 avril 1999, Marrakech.

El Alaoui El Fels M.A. \& Roques A., 2006a. Guide d'identification franco-arabe des ravageurs des cônes et des graines des résineux autochtones $d u$ Haut Atlas occidental. El Watanya, Marrakech, $66 \mathrm{p}$.

El Alaoui El Fels M. A \& Roques A., 2006b. Les arthropodes associés aux galbules et aux graines des genévriers autochtones dans la partie sud du bassin méditerranéen. In: Proceedings 3rd International Conference on Juniperus thurifera. Soria, Spain, 2427 mai 2006 : 437-446.

Falke B., 2004. Die Verjüngungsproblematik des Wacholders in Nordwestdeutschland: Welchen einfluss haben spezialisierte Samenprädatoren? Mitt. Deutsch. Gesell. f. allgemeine angew. Entomol. 14: 49-52.

Garcı́́ D., 1998. Interaction between juniper Juniperus communis L. and its fruit insect pests: pest abundance, fruit characteristics and seed viability. Acta Oecologica 19: 517-525.

Garciá D., 2001. Effects of seed dispersal on Juniperus communis recruitment on a Mediterranean mountain. J. Veget. Sc. 12: 839-848.

Garciá D., Zamora R., Gómez J.M., Jordano P. \& Hódar J.A., 2000. Geographical variation in seed production, predation and abortion in Juniperus communis throughout its range in Europe. J. Ecol. 88: 436-446.

Garciá D., Zamora R., Gómez J.M. \& Hódar J.A., 2002. Annual variability in reproduction of Juniperus communis L. in a Mediterranean mountain: relationship to seed predation and weather. Ecoscience 9: 251-255.

Gauquelin T., Bertaudière V., Cambecèdes J. \& Largier G., 2003. Le Genévrier thurifère (Juniperus thurifera L.) dans les Pyrénées : état de conservation et perspectives. Acta Bot. Barc. 49 : 83-94.

Graora D., Spasi R. \& Čkrkić M., 2010. Carulaspis juniperi (Bouché) - juniper pest (Juniperus spp.) in the Belgrade area. Belgrade, Arch. Biol. Sci. 62: 1207-1214.

Guido M., Battisti A. \& Roques A., 1995. A contribution to the study of cone and seed pests of the evergreen cypress (Cupressus sempervirens L.) in Italy. Redia 78: 211-227.

Guido M., Battisti A. \& Roques, A. 1998. Mortality factors affecting cones and seeds of the evergreen cypress, Cupressus sempervirens, in the predispersal phase. In: Battisti A. \& Turgeon J.J. (eds.), Proc. $5^{\text {th }}$ Cone and Seed Insects IUFRO Working Party Conference. Inst. Agric. Entomol. Padova: 209-214.

Janzen D.H., 1971. Seed predation by animals. Annu. Rev. Ecol. Syst. 2: 465-492.

Mendel Z., Assael F., Saphir N., Zehavi A., Nestel D. \& Schiller G., 1997. Seedling mortality in regeneration of Aleppo pine following fire and attack by the scale insect Matsucoccus josephi. Journal of Wildland Fire 7: 327-333.

Miller W. E., 1978. Use of prescribed burning in seed production areas to control red pine cone beetle. Environmental Entomology 7: 698-702.

Ordóñez J. L. \& Retana J., 2004. Early reduction of post-fire recruitment of Pinus nigra by post-dispersal seed predation in different time-since-fire habitats. Ecography 27: 449-458.
Peters V.S., Macdonald S.E. \& Dale M.R.T., 2005. The interaction between masting and fire is key to white spruce regeneration. Ecology 86: 1744-1750.

Poncet B.N., Garat P., Manel S., Bru N., Sachet J.M., Roques A. \& Desprès L., 2009. The effect of climate on masting in the European larch and on its specific seed predators. Oecologia 159: 527-537.

Rodrigo A., Retana J., Pico F.X., 2004. Direct regeneration is not the only response of mediterraanean forests to large fires. Ecology 85: 716-729.

Roques A., 1983. Les insectes ravageurs des cônes et graines de conifères en France. INRA, Service des publications, Versailles, $135 \mathrm{p}$.

Roques A. \& Auger-Rozenberg M.A., 2006. L'incendie pourrait-il constituer un mécanisme de régénération naturelle du Genévrier thurifère par échappement aux ravageurs des graines? L'exemple de la montagne de Rié (France. In: Proceedings 3rd International Conference on Juniperus thurifera. Soria, Spain, 24-27 mai 2006) : 407-417.

Roques A. \& El Alaoui El Fels M.A., 2002. Overview of the arthropod fauna exploiting seed cones in the Mediterranean Basin. In: Lieutier F. \& Ghaioule D. (eds.), Entomological Research in Mediterrannean Forest Ecosystems, INRA Éditions, Versailles: 5978.

Roques A., Markalas S., Roux G., Pan Y.Z., Sun J.H. \& Raimbault J.P., 1999. Impact of insects damaging seed cones of cypress, Cupressus sempervirens, in natural stands and plantations of South-eastern Europe. Ann. For. Sci. 56: 167-177.

Roques A., Raimbault J. P. \& Goussard F., 1984. La colonisation des cônes et galbules des genévriers méditerranéens par les insectes et acariens et son influence sur les possibilités de régénération naturelle de ces essences. Ecol. Medit. 10 : 147-169.

Roques A., Skrzypczyńska, M. 2003. Seed-infesting chalcids of the genus Megastigmus Dalman (Hymenoptera: Torymidae) native and introduced to Europe: taxonomy, host specificity and distribution. J. Natur. Hist. 37: 127-238.

Rouault G., Cantini R., Battisti A. \& Roques A., 2005. Geographic distribution and ecology of two species of Orsillus (Hemiptera: Lygaeidae) associated with cones of native and introduced Cupressaceae in Europe and the Mediterranean Basin. Can. Entomol. 137: 450-470.

Saint-Germain M., Drapeau P. \& Buddle C.M., 2008. Persistence of pyrophilous insects in fire-driven boreal forests: population dynamics in burned and unburned habitats. Diversity Distrib. 14: 713-720.

Silvertown J., 1980. The evolutionary ecology of the mast seeding in trees. Biol. J. Linn. Soc. 14: 235250.

Turgeon J., Roques A. \& De Groot P., 1994. Insect fauna of coniferous seed cones: diversity, host plant interactions, impact and management. Ann. Rev. Entomol. 39: 175-208.

Verheyen K., Adriaenssens S., Gruwez R., Michalczyk I.M., Ward L.K., Rosseel Y., Van den Broeck A. \& Garcıá D., 2009. Juniperus communis: victim of the combined action of climate warming and nitrogen deposition? Plant Biol. 11: 49-59.

Wade D. D., Debarr G. L., Barber L. R \& Manchester E., 1989. Prescribed fire - a cost effective control for white pine cone beetle. In: MacIver D.C., Auld H. \& Whitewood R (eds), Proceedings of the 10th Conference on Fire and Forest Meteorology, Ottawa, Ontario, Canada: 117-121. 